\title{
Preliminary survey of the pinewood nematode in Turkey
}

\author{
Suleyman Akbulut1, Paulo Vieira², Alexander Ryss³, Besir Yuksel11, Akif Keten'1, Manuel Mota² \\ and Vera Valadas² \\ 1Duzce University, Faculty of Forestry,Duzce, 81620 (Turkey); e-mail: akbulutsuleyman@yahoo.com \\ 2NemaLab/ICAM, Departmento de Biologia, Universidade de Évora, 7002-554 Évora (Portugal) \\ 3Zoological Institute RAS, Universitetskaya Naberezhnaya 1, Sankt Peterburg 199034 (Russia)
}

\begin{abstract}
A survey was conducted in the northern conifer forests of Turkey in 2003 and 2004 for the pinewood nematode, Bursaphelenchus xylophilus. Wood samples were collected from declining pine trees, located in the following target areas: Düzce, Ankara, Bolu, and Artvin. Nematodes were extracted from over 310 samples and were observed and identified. B. xylophilus was not detected in any samples. Bursaphelenchus species were only found in $6 \%$ of the samples. From the B. xylophilusgroup, only the species $B$. mucronatus was reported. Species identification was performed from morphological characters, particularly male spicules, and by molecular analysis with ITS-RFLP.
\end{abstract}

\section{Introduction}

Turkey is located on an area of transition between Europe and Asia. 26\% of the country's land area is forests ( 21 million ha), of which only half is productive. Despite the enormous size of Turkey's forests, and their great biodiversity, Turkey imports large amounts of wood, importing almost 1 million $\mathrm{m}^{3}$ of industrial coniferous wood in 1999 (DPT, 2001). The liberalization of international trade has increased the risk of introduction of nonindigenous species along with the increase in trade. Such species could harm countries' natural resources, and the goods and services which rely on them, thus countries face a new challenge of protecting their resources from this threat (Mack et al., 2000; Sakai et al., 2001).

The detection in Portugal of the pinewood nematode, Bursaphelenchus xylophilus (Steiner \& Buhrer, 1934) Nickle, 1970 , marks one of the most recent introductions of an invasive species into pine forest ecosystems in Europe. This nematode is the causal agent of pine wilt disease (Mota et al., 1999) and is on the EPPO A1 list of pests recommended for regulation as quarantine pests. Following the detection of B.xylophilus in one of the member states of the European Union, specific measures to control and eradicate both the nematode and its insect vectors, Monochamus spp., from the affected area in Portugal were put into place in accordance with Directive 2001/219/EC. This directive also required surveys of $B$. xylophilus to be performed in other pine forests both within Portugal and in other members of the EU. Turkey, although not a member of the EU, has aligned its phytosanitary regulations with the EU ones.

The presence and distribution of Bursaphelenchus species in Turkey is poorly known. The first report of the genus Bursaphelenchus was made rather recently (Vieira et al., 2003) and knowledge about species present in Turkey is limited to several short reports (Vieira et al., 2004). In order to study the species of Bursaphelenchus associated with pine trees, in particular the members of the xylophilus-group, and to evaluate the potential risk of introduction into Turkey of $B$. xylophilus, a preliminary survey was conducted in 2003 and 2004 in several target areas in the northern shore region of Turkey.

\section{Materials and Methods}

In 2003-04 a survey was conducted in the pine forest areas of Ankara, Artvin, Düzce, Istanbul, Samsun and Trabzon, in Turkey. Wood samples, each 40-80 g in mass, were collected from pine trees (Table 1) displaying declining symptoms, $1.5 \mathrm{~m}$ up the trunk (DBH). A Pressler borer was used to sample from both sides of each tree, and samples were stored in polythene bags. Nematodes were extracted using a modified Baermann funnel technique, and processed within $48 \mathrm{~h}$. The collected nematodes were inoculated on Botrytis cinerea growing in malt agar, and incubated for 2 weeks at $25^{\circ} \mathrm{C}$.

For nematode identification, special attention was given to the group of species closely similar to B. xylophilus (xylophilusgroup sensu; Ryss et al., 2005). Morphological identification was used to determine whether a species was part of the B. xylophilusgroup, based on the following characters which define the species

Table 1 Number of wood samples, collected at each region, and respective host tree. The number of samples with Bursaphelenchus specimens is given in brackets

\begin{tabular}{|c|c|c|c|c|c|c|}
\hline Host tree & Ankara & Artvin & Düzce & Istanbul & Samsun & Trabzon \\
\hline Pinus brutia & & & & 9 & 6 & \\
\hline Pinus nigra & $30(2)$ & & $26(6)$ & 13 & 49 & \\
\hline Pinus pinaster & & & $14(1)$ & 1 & & \\
\hline Pinus pinea & & & & 3 & & \\
\hline Pinus radiata & & & 1 & & & \\
\hline Pinus sylvestris & & $65(6)$ & $18(1)$ & 15 & 15 & $46(1)$ \\
\hline
\end{tabular}



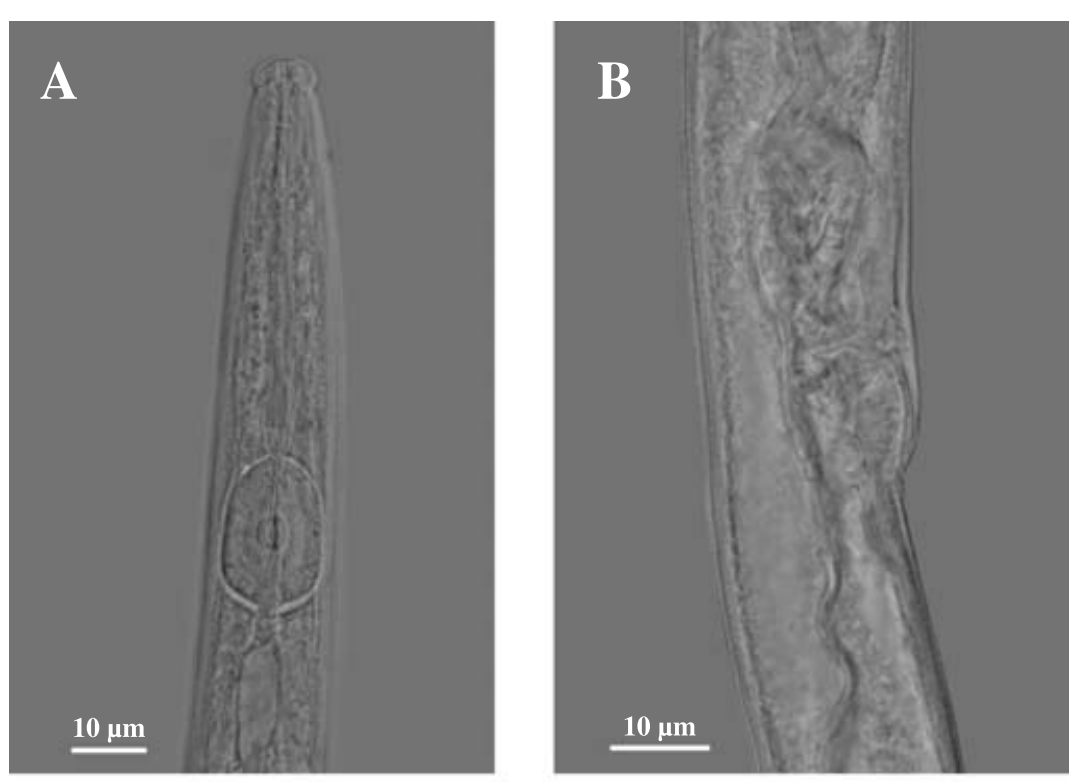

Fig. 1 Light optical microscope observations of Bursaphelenchus mucronatus. A: Anterior region; B: Vulva region; C: Male tail; D: Female tail.
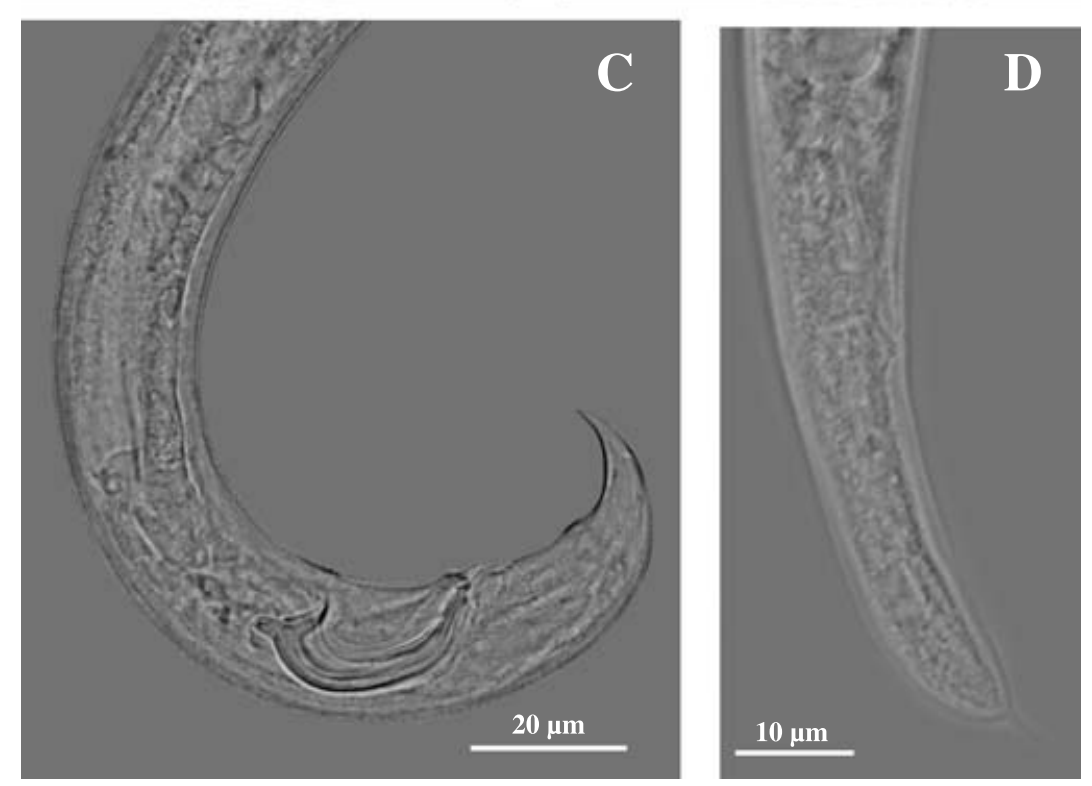

group: the typical shape of the spicule: capitulum flattened anteriorly, condylus small, dorsal contour of lamina distinctly angular in last third, cucullus present (Fig. 1), and which are sufficient to separate this species from the other groups of Bursaphelenchus species (Ryss et al., 2005).

Where a nematode was identified as belonging to the $B$. xylophilus-group, identification was performed to species level, using morphological and molecular methodologies. For optical microscopic studies (Olympus BX50), nematodes were fixed with hot formalin (4\%), processed to anhydrous glycerin and mounted in permanent slides according the 'express technique' described by Ryss (2003). The molecular analysis was performed following the methodology described in Cenis (1993) for DNA extraction, and the ITS-RFLP profiles were obtained following the methodology previously described in Hoyer et al. (1998) and Mota et al. (1999). Other Bursaphelenchus specimens were identified using only morphological methodologies, and only as far as the genus level.

\section{Results}

Only 17 of the 310 samples (6\%) taken contained Bursaphelenchus specimens (Table 1). Further details about the geographical distribution of these 17 samples, the host trees from which the samples were taken, and the Bursaphelenchus species in the samples are summarized in Table 2.

Morphological identification identified several nematodes as belonging to one species in the B. xylophilus-group. These nematodes were analyzed molecularly with ITS-RFLP and compared with those described in Burgermeister et al. (2005), 
Table 2 Host tree and localization of the Bursaphelenchus species found in north regions of Turkey

\begin{tabular}{|c|c|c|c|c|}
\hline Sample No & Location & Tree & Stand type & Bursaphelenchus sp. \\
\hline 1 & Ankara - ODTU campus & P. nigra & P. nigra & Bursaphelenchus sp. 1 \\
\hline 2 & Ankara - ODTU campus & P. nigra & P. nigra & Bursaphelenchus sp. 2 \\
\hline 3 & Artvin-Borçka & P. sylvestris & P. sylvestris & B. mucronatus \\
\hline 4 & Artvin-Borçka & P. sylvestris & P. sylvestris + Spruce & B. mucronatus \\
\hline 5 & Artvin-Borçka & P. sylvestris & Degraded $P$. sylvestris & Bursaphelenchus sp. 2 \\
\hline 6 & Artvin-Zeytinli & P. sylvestris & P. sylvestris & Bursaphelenchus sp. 2 \\
\hline 7 & Artvin-Zeytinli & P. sylvestris & P. sylvestris + Fir & B. mucronatus \\
\hline 8 & Artvin-Zeytinli & P. sylvestris & P. sylvestris + Fir + Spruce & B. mucronatus \\
\hline 9 & Düzce, Darıyeri & P. nigra & P. nigra & B. mucronatus \\
\hline 10 & Düzce, Konutlar & P. pinaster & P. pinaster & Bursaphelenchus sp. 2 \\
\hline 11 & Düzce, Kurugöl & P. nigra & P. nigra & B. mucronatus \\
\hline 12 & Düzce, Kurugöl & P. nigra & P. nigra & B. mucronatus \\
\hline 13 & Duzce, Kurugöl & P. nigra & P. nigra & B. mucronatus \\
\hline 14 & Düzce-Kurugöl & P. nigra & P. nigra & B. mucronatus \\
\hline 15 & Düzce-Kurugöl & P. nigra & P. nigra & B. mucronatus \\
\hline 16 & Düzce-Odayeri & P. sylvestris & Fir $+P$. sylvestris + Beech & B. mucronatus \\
\hline 17 & Trabzon-Torul & P. sylvestris & P. sylvestris & Bursaphelenchus sp. 2 \\
\hline
\end{tabular}

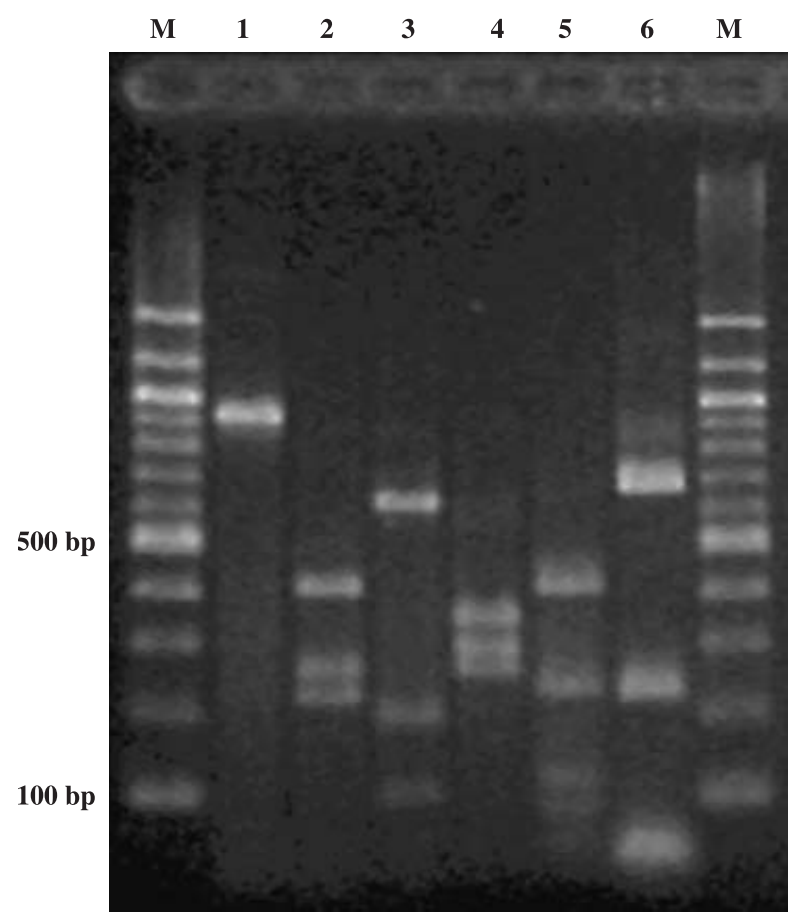

Fig. 2 ITS-RFLP patterns of B. mucronatus. Restriction fragments were obtained by digestion of the amplified rDNA fragment (1) with Rsa I (2), Hae III (3), Msp I (4), Hinf I (5) and Alu I (6). M: DNA size marker (100 bp ladder, Invitrogene).

and were clearly identified as Bursaphelenchus mucronatus Mamiya \& Enda (1979) (Fig. 2). Other morphological characters, such as the female vulval flap and the presence of a mucron in the female tail, matched the description of the species $B$. mucronatus (Fig. 1).
Two other species, within the $B$. pineperdae-group sensu Ryss et al. (2005) were detected from wood samples (Table 2), and referred to as Bursaphelenchus sp. 1 and sp. 2, are still being identified.

\section{Discussion}

This preliminary study is the first survey for B. xylophilus in Turkey and did not detect the presence of this species in any pine wood sample from the surveyed areas. B. mucronatus was the only species of the B. xylophilus-group to be found, mainly in the regions of Düzce and Artvin. This species is widely distributed in Europe (mainly in the northern and central countries), some countries of Asia, and has been reported once from Canada (for a detailed distribution see Ryss et al., 2005).

The pathogenicity of $B$. mucronatus to different pine trees has been studied by several authors (Braasch, 1996; Mamiya, 1999; Caroppo et al., 2000; Kulinich, 2004; MichalopoulosSkarmoutsos et al., 2004). Its pathogenic potential is still debatable according to some authors (Kulinich, 2004), while others state that this species, under natural conditions, is not a threat to forest ecosystems (Mamiya, 1999; McNamara, 2004). Besides that, B. mucronatus is one of the most abundant species in Europe and Asia, and no correlation or comparison has been made with the economic and natural impact caused by B. xylophilus in Portugal, or other Asian countries where this species has been reported as pathogenic to pine trees. Isolates of $B$. mucronatus found in Turkey, although associated with wilted or weakened pine trees, cannot be correlated with or established as the cause of the symptoms in, and ultimately the death of, pine trees.

Indigenous pine species (P. nigra, P. sylvestris) and the introduced species ( $P$. pinaster) (DPT, 2001), the main species of conifer forests in Turkey, constitute a group of highly vulnerable trees which show high susceptibility to B. xylophilus (Evans 
et al., 1996; McNamara, 2004). Other species (P. brutia, P. radiata) have been reported as associated host trees of the pinewood nematode (Ryss et al., 2005) in other countries.

The close similarity between the biology of $B$. mucronatus and that of B. xylophilus; the presence and distribution of Monochamus galloprovincialis (which has been identified as a vector of B. xylophilus in Portugal) in Turkey, mainly in northern, southern and western areas (Çanakçığlu \& Mol, 1998; Özdikmen et al., 2005); and climatic conditions above $20^{\circ} \mathrm{C}$ in summer, define these areas as highly suitable for the possible establishment and survival B. xylophilus in Turkey.

A general survey for the pinewood nematode in these specific areas, the study of the Bursaphelenchus species present in the endemic and introduced pine species, as well as knowledge of other biological invading species are crucial to protect Turkish forests. Therefore, surveying for B. xylophilus in Turkey is continuing, in accordance with the recommendations of the EU and EPPO, and in order to study the distribution and biological importance of other Bursaphelenchus species across Turkey.

\section{Acknowledgements}

The project was supported partly by NATO (CLG-97881), the Abant Izzet Baysal University Scientific Research Project Commission, and the Scientific and Technological Research Council of Turkey (TUBITAK).

\section{Prospection préliminaire pour le nématode du pin Bursaphelenchus xylophilus en Turquie}

Une prospection a été conduite dans les forêts de conifères du Nord de la Turquie en 2003 et 2004 pour détecter le nématode du pin, Bursaphelenchus xylophilus. Des échantillons de bois ont été collectés sur des pins mourants, situés dans les zones suivantes: Düzce, Ankara, Bolu, et Artvin. Des nématodes ont été extraits de plus de 310 échantillons et ont été observés et identifiés. B. xylophilus n'a été détecté dans aucun échantillon. Des espèces de Bursaphelenchus n'ont été trouvées que dans $6 \%$ des échantillons. Dans le groupe de B. xylophilus, seule l'espèce $B$. mucronatus a été signalée. L'identification des espèces a été réalisée à partir de caractères morphologiques, en particulier les spicules du mâle, et par analyse moléculaire par ITS-RFLP.

\section{Предварительное обследование на выявление сосновой древесной нематоды в Турции}

В 2003 и 2004 г. в хвойных лесах севера Турции проводилось обследование на выявление сосновой древесной нематоды Bursaphelenchus xylophilus. Образцы древесины отбирались с отмирающих сосен, находившихся в следующих областях: Дющче, Анкара, Болу и Артвин. Нематоды экстрагировались из 310 образцов, подвергались наблюдению и идентификации. B. xylophilus не был обнаружен ни в одном из образцов. Виды рода Bursaphelenchus были найдены только в $6 \%$ образцов. Из группы B. xylophilus зарегистрирован только вид В. mucronatus. Идентификация видов выполнялась по морфологическим признакам, в частности по мужским спикулам, а также по молекулярным анализам с помощью ITS-RFLP.

\section{References}

Braasch H (1996) [Pathogenicity testing with Bursaphelenchus mucronatus on pine and spruce samples in Germany]. European Journal of Forest Pathology 26, 205-216.

Burgermeister W, Metge K, Braasch H \& Buchbach E (2005) ITS-RFLP patterns for differentiation of 26 Bursaphelenchus species (Nematoda: Parasitaphelenchidae) and observations on their distribution. Russian Journal of Nematology 13, 29-42.

Çanakçığlu H \& Mol T (1998) Forest Entomology: Harmful and Beneficial Insects. Istanbul University Publication no: 4063 (TR) (in Turkish).

Caroppo S, Cavalli M, Coniglio D \& Ambrogioni L (2000) Pathogenicity studies with various Bursaphelenchus populations on conifer seedlings under controlled and open air conditions. Redia LXXXIII, 61-75.

Cenis JL (1993) Identification of four major Meloidogyne spp. by random amplified polymorphic DNA (RAPD-PCR). Phytopathology 83, 7680.

DPT (2001) T.R. Prime Ministry State Planning Organization. Long-term strategy and Eighth Five-year development Plan (2001-05). Ankara (TR).

Evans HF, McNamara DG, Braasch H, Chadouef J \& Magnusson C (1996) Pest risk analysis (PRA) for the territories of the European Union (as PRA area) on Bursaphelenchus xylophilus and its vectors in the genus Monochamus. Bulletin OEPP/EPPO Bulletin 26, 199-249.

Hoyer U, Burgermeister W \& Braasch H (1998) Identification of Bursaphelenchus species (Nematoda: Aphelenchoididae) on the basis of amplified ribosomal DNA (ITS-RFLP). Nachrichtenblatt des Deutschen Pflanzenschutzdienstes 50, 273-277.

Kulinich O (2004) Surveys for the pine wood nematode in Russia. In: The Pinewood Nematode, Bursaphelenchus xylophilus (Ed. Mota, M \& Vieira, P), pp. 65-75. Proceedings of an International Workshop, University of Évora, Portugal. Nematology Monographs and Perspectives 1, BRILL, Leiden (NL).

Mack RN, Simberloff D, Lonsdale WM, Evans H, Clout M \& Bazzaz FA (2000) Biotic invasions: causes, epidemiology, global consequences, and control. Ecological Applications 10, 689-710.

Mamiya Y (1999) Review on the pathogenicity of Bursaphelenchus mucronatus. In: Sustainability of Pine Forests in Relation to Pine Wilt and Decline. Proceedings of International Symposium (Ed. Susuki, K), pp. 57-64. Tokyo (JP).

Mamiya Y \& Enda N (1979) Bursaphelenchus mucronatus n. sp. (Nematoda: Aphelenchoididae) from pinewood and its biology and pathogenicity to pine trees. Nematologica 25, 353-361.

McNamara DG (2004) Quarantine concerns about the methods used to demonstrate pathogenicity of Bursaphelenchus spp. In: The Pinewood Nematode, Bursaphelenchus Xylophilus (Ed. Mota, M \& Vieira, P), pp. 187-197. Proceedings of an International Workshop, University of Évora, Portugal. Nematology Monographs and Perspectives 1, BRILL, Leiden (NL).

Michalopoulos-Skarmoutsos H, Skarmoutsos G, Kalapanida M \& Karageorgos A (2004) Surveying and recording of nematodes of the genus Bursaphelenchus in conifer forests in Greece and pathogenicity of the most important species. In: The Pinewood Nematode, Bursaphelenchus Xylophilus (Ed. Mota, M \& Vieira, P), pp. 113-126. Proceedings of an International Workshop, University of Évora, Portugal. Nematology Monographs and Perspectives 1, BRILL, Leiden (NL). 
Mota M, Braasch H, Bravo MA, Penas AC, Burgermeister W, Metge K \& Sousa E (1999) First report of Bursaphelenchus xylophilus. Portugal and Europe. Nematology 1, 727-734.

Özdikmen H, Özdemir Y \& Turgut S (2005) Longhorned beetles collection of the Nazife Tuatay Plant Protection Museum, Ankara, Turkey (Coleoptera, Cerambycidae). Journal of the Entomological Research Society 7, 1-33. Ryss A (2003) Express technique to prepare permanent slides of nematodes. Zoosystematica Rossica 11, 257-260.

Ryss A, Vieira P, Mota M \& Kulinich O (2005) A synopsis of the genus Bursaphelenchus Fuchs, 1937 (Aphelenchida: Parasitaphelenchidae) with keys to species. Nematology 7, 393-458.
Sakai AK, Allendorf FW, Holt JS, Lodge DM, Molofsky J, With KA, Baughman S, Cabin RJ, Cohen JE, Ellstrand NC, McCauley DE, O'Neil JE, Parker IM, Thompson JN \& Weller SG (2001) The population biology of invasive species. Annual Review of Ecology Systematics 32, 305-332. Vieira P, Akbulut S, Mota M \& Valadas V (2003) First report of Bursaphelenchus sp. from Turkey, associated with Pinus nigra. Journal of Nematology 35, 369.

Vieira P, Valadas V, Akbulut S, Mota M \& Ryss A (2004) First report of Bursaphelenchus mucronatus from Turkey, associated with Pinus nigra. XXVII. European Society of Nematologists International Symposium, Rome, 235. 